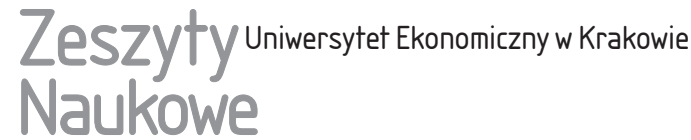

\section{Integracja europejska w obliczu eurosceptycyzmu}

\section{Streszczenie}

Poglądy eurosceptyczne są coraz częściej wyrażane w programach i działaniach partii politycznych. Zauważalne są także w debacie politycznej w wybranych państwach członkowskich. Celem artykułu jest odpowiedź na pytanie, czy eurosceptycyzm jest szansą, czy zagrożeniem dla przyszłości idei integracji oraz czy zagrożona jest spójność projektu europejskiego.

W artykule zdefiniowano pojęcie eurosceptycyzmu i przedstawiono jego wybrane kategoryzacje. Na podstawie przeprowadzonej analizy ilościowej, a także studium literatury przedmiotu podjęto próbę oceny znaczenia eurosceptyków w Parlamencie Europejskim. W artykule starano się również zidentyfikować przyczyny popularności poglądów eurosceptycznych w Europie, wskazując na istnienie kryzysu gospodarczego, migracyjnego, demokracji, a także samego projektu, jakim jest UE.

Na podstawie przeprowadzonych rozważań stwierdzono, że wzrosła liczba eurosceptyków w PE, są oni jednak podzieleni między różne grupy polityczne. Istnieje potrzeba ich większej konsolidacji i wypracowania przez nich spójnych postulatów - wtedy, paradoksalnie, eurosceptycy mogą stać się szansą dla przyszłości europejskiego projektu. Poglądy eurosceptyczne nie powinny być marginalizowane, ale traktowane $\mathrm{z}$ uwagą w imię zachowania wartości, jaką jest integracja.

Słowa kluczowe: eurosceptycyzm, Parlament Europejski, eurofobowie, grupy polityczne. Klasyfikacja JEL: F02, F5.

Aleksandra Pleśniarska, Uniwersytet Ekonomiczny w Krakowie, Wydział Ekonomii i Stosunków Międzynarodowych, Katedra Europejskiej Integracji Gospodarczej, ul. Rakowicka 27, 31-510 Kraków, e-mail: aleksandra.plesniarska@uek.krakow.pl 


\section{Wprowadzenie}

Unia Europejska jako organizacja międzynarodowa jest wymiernym efektem procesu integracji rozpoczętej kilkadziesiąt lat temu na kontynencie europejskim. Integracja ta przebiegała w kilku etapach, obejmujących zarówno proces pogłębiania współpracy między państwami, jak i poszerzanie obszaru działania (kolejne rozszerzenia o nowe państwa członkowskie). Wydaje się, że dotychczasowe ukierunkowanie współpracy między krajami na zapewnienie harmonijnego i zrównoważonego wzrostu gospodarczego we wszystkich państwach członkowskich, podnoszenie i wyrównywanie poziomu życia w poszczególnych regionach czy podejmowanie działań sprzyjających spójności gospodarczej przy jednoczesnej dbałości o zachowanie zasady solidarności nie byłoby możliwe bez akceptacji idei integracji i społecznego entuzjazmu wobec niej. W ostatnich latach obserwowany jest jednak wyraźny wzrost negatywnych nastrojów i postaw wobec Unii Europejskiej. Wydaje się także, że eurosceptycyzm nie jest tylko przejawem funkcjonowania państw demokratycznych, w których respektowana jest zasada pluralizmu politycznego, lecz staje się coraz bardziej zauważalny w ramach głównego nurtu politycznego. Poglądy eurosceptyczne są coraz częściej artykułowane w programach i działaniach partii politycznych w Europie czy grup politycznych w Parlamencie Europejskim. W ostatnich latach konsekwentnie zyskują także coraz większe poparcie społeczne. Dodatkowo obserwowany jest wyraźny regres procesów integracyjnych. Warto zatem zwrócić uwagę na zagadnienie eurosceptycyzmu w kontekście rozważań prowadzonych na temat wyzwań i zagrożeń związanych z dalszą integracją europejską. Celem artykułu jest odpowiedź na pytanie, czy eurosceptycyzm jest zatem szansą, czy zagrożeniem dla przyszłości idei integracji oraz czy zagrożona jest spójność projektu europejskiego.

Analiza danych empirycznych, a także studia literatury przedmiotu mają służyć odpowiedzi na następujące pytania badawcze: jak jest rozumiane pojęcie eurosceptycyzmu w literaturze przedmiotu? jakie jest znaczenie eurosceptyków w Parlamencie Europejskim? jakie są przyczyny i konsekwencje rosnącej popularności postaw eurosceptycznych dla przyszłości Unii Europejskiej?

\section{Eurosceptycyzm - dylematy definicyjne}

Postępujący proces integracji europejskiej implikuje konieczność teoretycznej konceptualizacji pojęć, które określają różnorodne postawy wobec zjawiska europeizacji. Jednym z takich terminów jest „eurosceptycyzm”. Odwołując się do literatury przedmiotu, niezwykle trudno jest wskazać na jedną uniwersalną definicję tego pojęcia. Termin ,eurosceptycyzm” pojawił się po raz pierwszy 
najprawdopodobniej w połowie lat 80 . w brytyjskich leksykonach polityki i dziennikarstwa. Oxford English Dictionary (odwołując się do dziennika „The Times” z 1986 r.) definiuje eurosceptyka jako „osobę, która nie jest entuzjastyczna wobec zwiększania władzy Unii Europejskiej" [Harmsen i Spiering 2004, s. 15]. Wraz $\mathrm{z}$ rozpoczęciem debaty na temat ratyfikacji traktatu z Maastricht termin ten zyskał na popularności także w innych krajach europejskich [Harmsen i Spiering 2004]. W 1998 r. P. Taggart, dokonując analizy systemów partyjnych w 15 państwach członkowskich UE oraz w Norwegii, tłumaczył eurosceptycyzm jako „zarówno warunkową, jak również stanowczą i całkowitą opozycję wobec procesu integracji europejskiej" [Taggart 1998, Moroska 2010].

P. Taggart i A. Szczerbiak wyróżnili eurosceptycyzm miękki (soft) i twardy (hard). Ten ostatni określa postawę kategorycznie odrzucającą samą ideę integracji europejskiej, a tym samym wyrażającą swój sprzeciw wobec Unii Europejskiej, a także uczestnictwa własnego kraju w procesach integracyjnych. Eurosceptycyzm miękki nie wyraża natomiast zasadniczego sprzeciwu wobec samej idei integracji europejskiej czy członkostwa w UE, ale wyraża zastrzeżenia wobec jednego lub wielu aspektów integracji europejskiej, co w efekcie prowadzi do częściowej lub warunkowej opozycji wobec UE [Taggart i Szczerbiak 2003].

P. Kopecký i C. Mudde zakwestionowali użyteczność typologii P. Taggarta i A. Szczerbiaka. Zaproponowali alternatywną kategoryzację tego pojęcia. W zależności od postawy przyjmowanej wobec integracji europejskiej, wyróżnili: euroentuzjastów, eurosceptyków, europragmatyków i europrzeciwników (tabela 1). Warto podkreślić, że europragmatycy nie popierają integracji europejskiej, ale ze względów pragmatycznych pozytywnie odnoszą się do Unii Europejskiej, postrzegając ją w kategoriach korzyści dla ich własnego kraju lub potencjalnych zysków wyborczych, zaś eurosceptycy popierają ideę integracji europejskiej, lecz ich zdaniem Unii Europejska nie jest najlepszym sposobem na osiągnięcie tego celu [Toomey 2007, Moroska 2010].

Tabela 1. Typologia postaw wobec integracji europejskiej według P. Kopecký’ego i C. Muddego

\begin{tabular}{|l|c|c|}
\hline \multicolumn{1}{|c|}{ Typologia postaw } & $\begin{array}{c}\text { Poparcie dla idei integracji } \\
\text { europejskiej }\end{array}$ & Poparcie dla Unii Europejskiej \\
\hline Euroentuzjaści & tak & tak \\
\hline Eurosceptycy & tak & nie \\
\hline Europragmatycy & nie & tak \\
\hline Europrzeciwnicy & nie & nie \\
\hline
\end{tabular}

Źródło: opracowanie własne na podstawie [Kopecký i Mudde 2002, s. 302-303; Moroska 2010, s. 59-60]. 
Warto wspomnieć, że P. Taggart i A. Szczerbiak uznali krytykę swej typologii za konstruktywną i zaproponowali w 2003 r. swoistą redefinicję terminologii. Podkreślili, że zasadnicza zmienna określająca stosunek partii do integracji powinna odwoływać się do poparcia, względnie opozycji, wobec projektu integracji europejskiej, a także stosunku do dalszego poszerzania kompetencji UE [Moroska 2010]. Wobec tego eurosceptycyzm twardy oznacza zasadniczy sprzeciw wobec projektu integracji europejskiej w postaci Unii Europejskiej, polegającego na przeniesieniu uprawnień (władzy) na poziom ponadnarodowy. Natomiast eurosceptycyzm miękki nie wyraża zasadniczego sprzeciwu wobec integracji europejskiej, jest jednak w opozycji do obecnego i przyszłego rozwoju UE ukierunkowanego na dalsze poszerzanie jej kompetencji [Taggart i Szczerbiak 2003].

Wyjaśniając znaczenie terminu ,eurosceptycyzm”, należy pamiętać o czynnikach społeczno-politycznych każdego z państw. Słuszne wydaje się stwierdzenie R. Harmsena i M. Spieringa [2004, s. 17-18], że „tam, gdzie termin eurosceptycyzm jest zaadaptowany do specyficznych narodowych debat politycznych, przyjmuje znaczenie, które musi być rozumiane z uwzględnieniem różnych tradycji politycznych i doświadczeń z integracją europejską, które owe debaty kształtują".

Rozszerzając nieco obszar prowadzonych rozważań nad konceptualizacją pojęcia eurosceptycyzmu, warto odwołać się również do terminu „EUROsceptycyzm”, rozumianego jako „zestaw postaw i poglądów, jak również zachowań i działań krytycznych i opozycyjnych wobec unii walutowej w zjednoczonej Europie" [Riedel i Zuba 2015, s. 34]. Parafrazując przywoływane wcześniej kategoryzacje, R. Riedel i K. Zuba [2015] wyróżnili EUROsceptycyzm twardy i miękki. EUROsceptycyzm twardy neguje projekt integracji walutowej w ogóle. EUROsceptycyzm miękki dopuszcza istnienie unii walutowej bądź wiąże się z przejawianiem postawy krytycznej wobec wybranych jej aspektów (np. wobec sformułowania kryteriów konwergencji czy ponadnarodowego nadzoru bankowego), ale nie neguje idei integracji walutowej jako takiej.

Zaprezentowane definicje eurosceptycyzmu nie wyczerpują katalogu definicji proponowanych w literaturze przedmiotu. Warto zauważyć, że pojęcie to można rozumieć wielowymiarowo (tabela 2).

Odnosząc się do pojęcia eurosceptycyzmu, warto wskazać aspekty, które są zazwyczaj przedmiotem krytyki wyrażanej przez eurosceptyków wobec postępującej integracji europejskiej. Formułują oni zazwyczaj zarzuty odnoszące się m.in. do: braku uzasadnienia istnienia Unii Europejskiej jako takiej, procesu rozszerzania i pogłębiania integracji europejskiej (pytają tym samym o istnienie granic integracji), wartości, na których jest oparta UE, funkcjonowania systemu instytucjonalnego (słabej legitymizacji), funkcjonowania UE w wymiarze gospodarczym (dotyczące głównie polityki UE wobec działania gospodarki wolnorynkowej), ale także społeczno-kulturowym. 
Tabela 2. Aspekty znaczeniowe pojęcia eurosceptycyzmu

\begin{tabular}{|c|c|c|c|}
\hline \multicolumn{4}{|c|}{ Eurosceptycyzm } \\
\hline $\begin{array}{c}\text { w aspekcie } \\
\text { ekonomicznym }\end{array}$ & $\begin{array}{l}\text { W aspekcie } \\
\text { suwerenności }\end{array}$ & $\begin{array}{c}\text { w aspekcie } \\
\text { demokratycznym }\end{array}$ & $\begin{array}{l}\text { w aspekcie } \\
\text { politycznym }\end{array}$ \\
\hline $\begin{array}{l}\text { Odnosi się do najważ- } \\
\text { niejszych korzyści } \\
\text { i kosztów wynikają- } \\
\text { cych z członkostwa } \\
\text { w Unii Europejskiej, } \\
\text { będących wynikiem } \\
\text { istnienia lub braku } \\
\text { współpracy }\end{array}$ & \begin{tabular}{|l} 
Wyraża poparcie \\
dla ponadnarodowej \\
współpracy w spra- \\
wach, w których \\
samodzielne działania \\
państwa nie są efek- \\
tywne (np. ochrona \\
środowiska czy walka \\
z przestępczością \\
zorganizowaną), ale \\
za niezwykle istotne \\
uznaje również \\
zachowanie przez \\
poszczególne państwa \\
zdolności do podejmo- \\
wania działań w sferze \\
społeczno-kulturowej
\end{tabular} & $\begin{array}{l}\text { Obecny system } \\
\text { instytucjonalny Unii } \\
\text { Europejskiej uznaje } \\
\text { za nieadekwatny } \\
\text { w zakresie demokra- } \\
\text { tycznej reprezentacji } \\
\text { i uczestnictwa oby- } \\
\text { wateli }\end{array}$ & $\begin{array}{l}\text { Ocenia działanie Unii } \\
\text { Europejskiej przez } \\
\text { pryzmat doktryny } \\
\text { politycznej }\end{array}$ \\
\hline
\end{tabular}

Źródło: opracowanie na podstawie [Condruz-Băcescu 2014, s. 55].

Podsumowując dotychczasowe rozważania, warto zauważyć, że niezwykle trudno jest wskazać uniwersalną definicję eurosceptycyzmu. Wydaje się jednak, że eurosceptycyzm jako taki należy postrzegać jako negatywną postawę wobec idei integracji czy Unii Europejskiej bądź jej konkretnych obszarów działania lub posiadanych kompetencji. Różnice w sposobie definiowania koncentrują się na wskazaniu stopnia natężenia wspomnianej negacji od umiarkowanego po radykalny. Trudności definicyjne wskazują zaś jednoznacznie na złożoność tego zagadnienia.

\section{Eurosceptycy w Parlamencie Europejskim}

Niemal od początków integracji europejskiej pojawiały się postawy sceptyczne wobec tej idei. Początkowo eurosceptyków kojarzono z Wielką Brytanią, współcześnie jednak poglądy te zyskują coraz większą popularność w całej Unii Europejskiej. Warto zwrócić szczególną uwagę na wyniki wyborów do Parlamentu Europejskiego (PE), wydaje się bowiem, że mogą być one uznane za emanację poglądów europejskiego społeczeństwa.

W ostatnich wyborach do Parlamentu Europejskiego w 2014 r. można było zauważyć wzrost poparcia dla partii politycznych, które uznawane są za euroscep- 
tyczne. Poglądy charakterystyczne dla twardego eurosceptycyzmu reprezentowane są m.in. przez niemiecką Narodowodemokratyczną Partię Niemiec (Nationaldemokratische Partei Deutschlands - NPD) czy brytyjską Partię Niepodległości Zjednoczonego Królestwa (United Kingdom Independence Party - UKIP), natomiast dla eurosceptycyzmu miękkiego m.in. przez polską partię Prawo i Sprawiedliwość (PiS) czy Alternatywę dla Niemiec (Alternative für Deutschland - AfD). Eurosceptyków będących obecnie w PE cechuje duża różnorodność. Łączy ich krytyka UE, ale trudno im wypracować wspólne, spójne postulaty [Łada 2014].

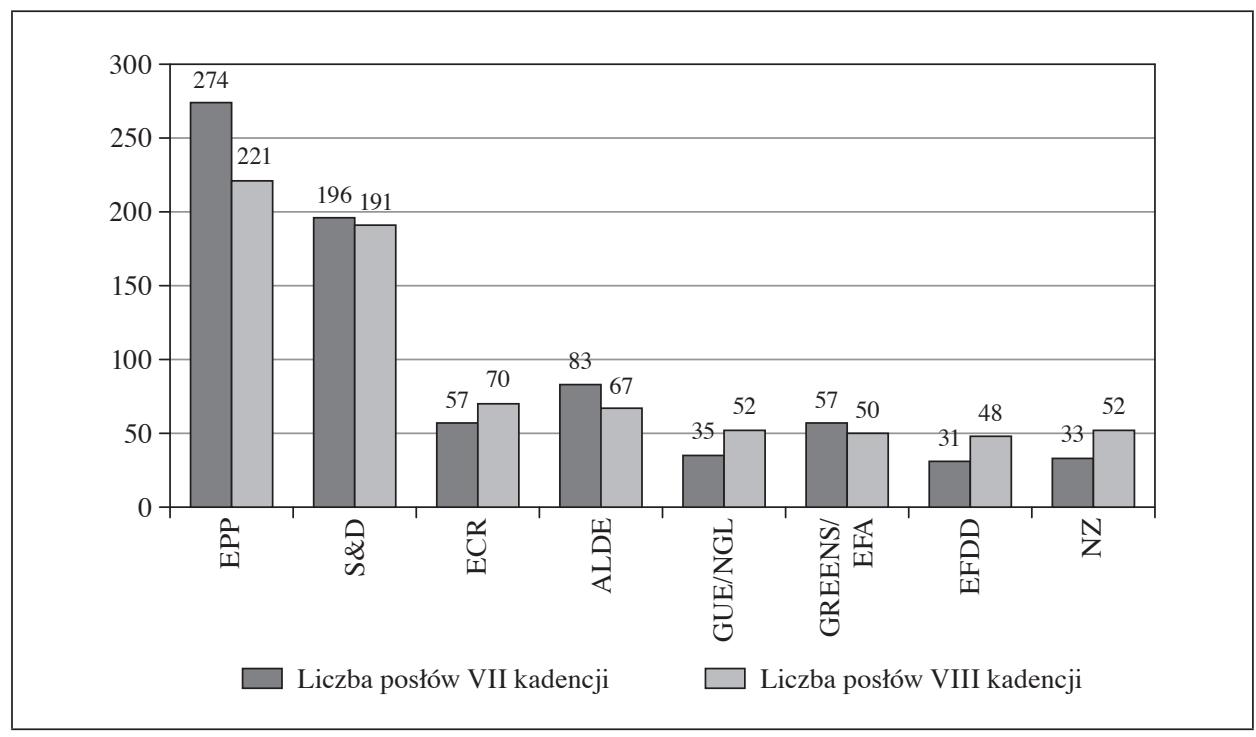

Objaśnienia: EPP - Grupa Europejskiej Partii Ludowej (Chrześcijańscy Demokraci), S\&D - Grupa Postępowego Sojuszu Socjalistów i Demokratów w Parlamencie Europejskim, ECR - Europejscy Konserwatyści i Reformatorzy, ALDE - Porozumienie Liberałów i Demokratów na rzecz Europy, GUE/NGL - Zjednoczona Lewica Europejska/Nordycka Zielona Lewica, GREENS/EFA - Zieloni/Wolny Sojusz Europejski, EFDD - grupa Europa Wolności i Demokracji Bezpośredniej, NZ - niezrzeszeni.

Rys. 1. Liczba posłów w Parlamencie Europejskim VII i VIII kadencji według grup politycznych

Źródło: opracowanie własne na podstawie [Wyniki wyborów... 2014].

Według różnych szacunków w wyborach do PE w 2014 r. eurosceptycy zdobyli ok. 100 na 751 miejsc [The Eurosceptic Union... 2014]. Jak zauważa A. Łada [2014], radykalnie eurosceptyczne partie zajęły ok. 11\% miejsc w Parlamencie Europejskim (w poprzedniej kadencji 8\%). Należy jednak pamiętać, by uwzględnić również wyniki tych partii, które prezentują tzw. miękki eurosceptycyzm (takich 
jak np. brytyjska Partia Konserwatywna). Wokół brytyjskiej partii UKIP powstała grupa Europa Wolności i Demokracji Bezpośredniej (Europe of Freedom and Direct Democracy - EFDD), natomiast grupa Europejskich Konserwatystów i Reformatorów (European Conservatives and Reformists - ECR) zrzesza tzw. miękkich eurosceptyków (pod względem liczby europosłów stała się ona trzecią co do wielkości grupą polityczną [Łada 2014]). Dane dotyczące liczby posłów PE VII i VIII kadencji według grup politycznych zaprezentowano na rys. 1.

Na uwagę zasługują również wyliczenia, które przeprowadzili Y. Bertoncini i N. Koenig [2014]. Wynika z nich, że 30 partii uznanych przez nich za eurosceptyczne (twardy eurosceptycyzm) z 18 państw członkowskich zdobyło w 2014 r. łącznie 125 miejsc w PE, natomiast 16 partii z 13 państw członkowskich, których przedstawiciele uznawani są za eurofobów ${ }^{1}$ zdobyło 85 miejsc (tabela 3).

Tabela 3. Eurosceptycy w Parlamencie Europejskim VIII kadencji

\begin{tabular}{|l|c|c|}
\hline \multicolumn{1}{|c|}{$\begin{array}{c}\text { Partie w Parlamencie } \\
\text { Europejskim }\end{array}$} & Liczba posłów & Liczba partii \\
\hline Eurosceptycy & $125(16,64 \%)$ & $30(16,3 \%)$ \\
\hline Eurofobowie & $82(10,92 \%)$ & $16(8,67 \%)$ \\
\hline Pozostałe & $544(72,44 \%)$ & $138(75 \%)$ \\
\hline Razem & $751(100 \%)$ & $184(100 \%)$ \\
\hline
\end{tabular}

Źródło: [Bertoncini i Koenig 2014, s. 3].

Europosłowie o poglądach eurosceptycznych stanowią większość zarówno w grupie politycznej ECR, jak i GUE/NGL (tabela 4). Natomiast relatywnie najwięcej przedstawicieli tzw. eurosceptycyzmu twardego jest w grupie EFDD, a także wśród europosłów niezrzeszonych. ECR uznawana jest za grupę reprezentującą umiarkowany eurosceptycyzm. Jej członkowie nie odrzucają koncepcji integracji europejskiej, ale sprzeciwiają się tworzeniu europejskiego superpaństwa. ECR opowiada się za bardziej elastyczną integracją europejską i szacunkiem wobec suwerenności narodowej. Jednym ze sloganów GUE/NGL jest hasło: „Inna Europa jest możliwa" (Another Europe is possible). Grupa ta nie sprzeciwia się idei integracji europejskiej ani UE, ale wyraźnie podkreśla konieczność zmian. Zdaniem europosłów z tej grupy Europa powinna opierać się na większej solidarności, równości i trwałości. Postulują również większą przejrzystość i większy udział demokracji bezpośredniej w UE. EFDD reprezentuje najbardziej radykalne poglądy eurosceptyczne ze wszystkich grup politycznych - sprzeciwia się dalszej integracji europejskiej [Bertoncini i Koenig 2014].

${ }^{1}$ Y. Bertoncini i N. Koenig pod pojęciem eurosceptyków rozumieją zwolenników eurosceptycyzmu miękkego, natomiast pod pojęciem eurofobów zwolenników eurosceptycyzmu twardego. 
Tabela 4. Eurosceptycy i eurofobowie według grup politycznych w Parlamencie Europejskim VIII kadencji

\begin{tabular}{|c|c|c|c|c|c|c|}
\hline \multirow{2}{*}{$\begin{array}{c}\text { Grupa } \\
\text { polityczna }\end{array}$} & \multirow{2}{*}{$\begin{array}{c}\text { Łączna } \\
\text { liczba miejsc } \\
\text { w PE }\end{array}$} & \multicolumn{2}{|c|}{ Liczba miejsc w PE } & \multirow{2}{*}{$\begin{array}{c}\text { Łączna } \\
\text { liczba partii } \\
\text { politycznych }\end{array}$} & \multicolumn{2}{|c|}{ Liczba partii politycznych } \\
\hline & & $\begin{array}{c}\text { euro- } \\
\text { sceptycy }\end{array}$ & $\begin{array}{c}\text { euro- } \\
\text { fobowie }\end{array}$ & & $\begin{array}{c}\text { euro- } \\
\text { sceptycy }\end{array}$ & $\begin{array}{c}\text { euro- } \\
\text { fobowie }\end{array}$ \\
\hline ECR & 70 & 54 & 4 & 24 & 12 & 1 \\
\hline GUE/NGL & 52 & 42 & 7 & 22 & 12 & 4 \\
\hline EFDD & 48 & 21 & 27 & 7 & 4 & 3 \\
\hline Niezrzeszeni & 52 & 8 & 44 & 15 & 4 & 8 \\
\hline
\end{tabular}

Źródło: opracowanie własne na podstawie [Bertoncini i Koenig 2014, s. 9 i 14].

Tabela 5. Partie polityczne o poglądach eurosceptycznych (twardy eurosceptycyzm) w wybranych państwach członkowskich i ich wyniki w wyborach do Parlamentu Europejskiego i parlamentów krajowych

\begin{tabular}{|c|c|c|c|c|c|}
\hline \multirow[t]{2}{*}{ Państwo } & \multirow[t]{2}{*}{$\begin{array}{l}\text { Partie poli- } \\
\text { tyczne (euro- } \\
\text { sceptycyzm } \\
\text { twardy) }\end{array}$} & \multicolumn{2}{|c|}{$\begin{array}{l}\text { Wyniki wyborów do parla- } \\
\text { mentów krajowych, które } \\
\text { odbyły się przed wyborami } \\
\text { do PE w } 2014 \text { r. }\end{array}$} & \multicolumn{2}{|c|}{$\begin{array}{l}\text { Wybory do Parlamentu } \\
\text { Europejskiego w } 2014 \text { r. }\end{array}$} \\
\hline & & wynik & pozycja & wynik & pozycja \\
\hline Austria & $\begin{array}{l}\text { Freedom } \\
\text { Party }\end{array}$ & $\begin{array}{l}20,51 \% \text { (wrze- } \\
\text { sień 2013) }\end{array}$ & 3 & $19,72 \%$ & 3 \\
\hline Dania & $\begin{array}{l}\text { Danish } \\
\text { People's Party }\end{array}$ & $\begin{array}{c}12,3 \% \text { (wrze- } \\
\text { sień 2011) }\end{array}$ & 3 & $26,60 \%$ & 1 \\
\hline Francja & National Front & $\begin{array}{l}13,60 \% \text { (czer- } \\
\text { wiec 2012) }\end{array}$ & 3 & $24,86 \%$ & 1 \\
\hline Holandia & $\begin{array}{l}\text { Party for Free- } \\
\text { dom }\end{array}$ & $\begin{array}{c}\text { 10,1\% (wrze- } \\
\text { sień 2012) }\end{array}$ & 3 & $13,32 \%$ & 3 \\
\hline $\begin{array}{l}\text { Wielka } \\
\text { Brytania }\end{array}$ & $\begin{array}{l}\text { United } \\
\text { Kingdom } \\
\text { Independence } \\
\text { Party }\end{array}$ & $\begin{array}{l}3,10 \%(\text { maj } \\
2010)\end{array}$ & $\begin{array}{c}\text { poza } \\
\text { parlamentem }\end{array}$ & $26,77 \%$ & 1 \\
\hline
\end{tabular}

Źródło: [Bertoncini i Koenig 2014, s. 16].

Oprócz tego, że po wyborach w 2014 r. zwiększyła się liczba eurosceptyków w PE, należy również odnotować ich dobre wyniki w poszczególnych państwach członkowskich UE. Partie uznawane ze eurosceptyczne (eurosceptycyzm twardy) zwyciężyły we Francji (skrajnie prawicowy Front Narodowy) i Wielkiej Brytanii (ultraprawicowa Partia Niepodległości Zjednoczonego Królestwa), a także w Danii (Duńska Partia Ludowa). Dobre wyniki uzyskały również partie, które odrzucają dotychczasowy model integracji europejskiej, np. w Holandii Partia Wolności 
czy w Austrii Wolnościowa Partia Austriacka [Staszczyk 2014]. Jak zauważają Y. Bertoncini i N. Koenig [2014], partie charakteryzujące się twardymi eurosceptycznymi poglądami stanowią ok. 1/10 Parlamentu Europejskiego, ale w wybranych państwach członkowskich znalazły się wśród trzech liczących się sił politycznych czy to w wyborach do parlamentów narodowych, czy do PE (tabela 5).

Należy zatem domniemywać, że dobre wyniki uzyskane w państwach członkowskich przez partie eurosceptyczne (reprezentujące eurosceptycyzm zarówno miękki, jak i twardy) dowodzą ich popularności w społeczeństwach państw członkowskich. Na uwagę zasługuje również fakt, że partie uznawane za eurosceptyczne jeszcze przed wyborami do PE stanowiły liczącą się siłę na scenie politycznej w swoim kraju, uzyskując dobre wyniki w wyborach do parlamentów krajowych (tabela 6).

Tabela 6. Partie polityczne uznawane za eurosceptyczne (miękki eurosceptycyzm) w wybranych państwach członkowskich i ich wyniki w wyborach do Parlamentu Europejskiego i parlamentów krajowych

\begin{tabular}{|c|c|c|c|c|c|}
\hline \multirow[t]{2}{*}{ Państwo } & \multirow[t]{2}{*}{$\begin{array}{l}\text { Partie uzna- } \\
\text { wane za euro- } \\
\text { sceptyczne }\end{array}$} & \multicolumn{2}{|c|}{$\begin{array}{l}\text { Wyniki wyborów do parla- } \\
\text { mentów krajowych, które } \\
\text { odbyły się przed wyborami } \\
\text { do PE w } 2014 \text { r. }\end{array}$} & \multicolumn{2}{|c|}{$\begin{array}{l}\text { Wybory do Parlamentu Euro- } \\
\text { pejskiego w } 2014 \text { r. }\end{array}$} \\
\hline & & wynik & pozycja & wynik & pozycja \\
\hline Finlandia & The Finns & $\begin{array}{l}\text { 1,05\% (kwie- } \\
\text { cień 2011) }\end{array}$ & 3 & $12,9 \%$ & 3 \\
\hline Grecja & Syriza & $\begin{array}{c}\text { 26,89\% (czer- } \\
\text { wiec 2012) }\end{array}$ & 2 & $26,58 \%$ & 1 \\
\hline Hiszpania & Plural Left & $\begin{array}{l}\text { 6,9\% (listopad } \\
\text { 2011) }\end{array}$ & 3 & $10,03 \%$ & 3 \\
\hline Polska & $\begin{array}{l}\text { Law and } \\
\text { Justice Party }\end{array}$ & $\begin{array}{l}29,89 \% \text { (paź- } \\
\text { dziernik 2011) }\end{array}$ & 2 & $31,78 \%$ & 2 \\
\hline Węgry & Jobbik & $\begin{array}{c}\text { 20,3\% (kwie- } \\
\text { cień 2014) }\end{array}$ & 3 & $14,67 \%$ & 2 \\
\hline $\begin{array}{l}\text { Wielka } \\
\text { Brytania }\end{array}$ & $\begin{array}{l}\text { Conservative } \\
\text { Party }\end{array}$ & $\begin{array}{c}36,1 \% \text { (maj } \\
2010)\end{array}$ & 1 & $23,31 \%$ & 3 \\
\hline Włochy & $\begin{array}{l}\text { Five Star } \\
\text { Movement }\end{array}$ & $\begin{array}{c}25,55 \% \text { (luty } \\
2013 \text { ) }\end{array}$ & 3 & $21,15 \%$ & 2 \\
\hline
\end{tabular}

Źródło: [Bertoncini i Koenig 2014, s. 12].

Warto zauważyć, że tzw. radykalni eurosceptycy nie uzyskali żadnych ważnych stanowisk w Parlamencie Europejskim, natomiast umiarkowani eurosceptycy zdobyli ich stosunkowo niewiele [Łada 2014]. Dane dotyczące liczby stanowisk w PE VIII kadencji według grup politycznych zaprezentowano w tabeli 7. 
Tabela 7. Liczba stanowisk w Parlamencie Europejskim VIII kadencji według grup politycznych

\begin{tabular}{|l|c|c|}
\hline Grupa polityczna & $\begin{array}{c}\text { Liczba przewodniczących } \\
\text { i wiceprzewodniczących PE/ } \\
\text { kwestorów }\end{array}$ & $\begin{array}{c}\text { Liczba przewodniczących } \\
\text { komisji }\end{array}$ \\
\hline EPP & $6 / 2$ & 9 \\
\hline S\&D & $4 / 1$ & 6 \\
\hline ECR & $1 / 1$ & 3 \\
\hline ALDE & $2 / 1$ & 1 \\
\hline GUE/NGL & $1 / 0$ & 1 \\
\hline GREENS/EFA & $1 / 0$ & 0 \\
\hline EFDD & $0 / 0$ & 0 \\
\hline Niezrzeszeni & $0 / 0$ & \\
\hline
\end{tabular}

Źródło: [Łada 2014, s. 9].

Podsumowując, należy zauważyć, że zwiększył się udział eurosceptyków w Parlamencie Europejskim w obecnej kadencji w stosunku do kadencji wcześniejszej. Uwzględniając ogólny wynik osiągnięty przez partie uznawane za eurosceptyczne, trudno mówić o tym, że są dominującą siłą na europejskiej scenie politycznej. Partie te są podzielone pomiędzy grupami politycznymi, brak im spójności. Nie można jednak marginalizować ich znaczenia. Wydaje się, że dla przyszłości UE szczególnie istotny powinien być fakt relatywnie dużej popularności partii eurosceptycznych w wybranych państwach członkowskich, tym bardziej że negatywne poglądy wobec obecnego kształtu integracji europejskiej zyskują swoich zwolenników także w krajach mających kluczowe znaczenie dla tej organizacji (np. we Francji).

\section{Eurosceptycyzm - przyczyny i konsekwencje dla przyszłości Unii Europejskiej}

Bez wątpienia na rozwój postaw negatywnych wobec UE mają wpływ określone uwarunkowania społeczno-gospodarcze i kulturowe danego państwa. Wydaje się jednak, że wspólnym mianownikiem dla niemal wszystkich państw członkowskich jest kryzys pojawiający się współcześnie na wielu płaszczyznach życia społeczno-gospodarczego. Wśród „kryzysów” europejskich należy wskazać m.in.: kryzys gospodarczy, kryzys demokracji, kryzys imigracyjny i kryzys koncepcji projektu europejskiego. Wydaje się, że brak stabilności w tak wielu kwestiach jednocześnie przyczynia się do zmiany poglądów społeczeństwa euro- 
pejskiego, które w zaistniałej sytuacji niejako naturalnie przyjmuje częściej sceptyczne czy wręcz negatywne stanowisko wobec UE.

A. Staszczyk [2014] wskazuje kryzys gospodarczy jako jedno ze źródeł sukcesu eurosceptyków w wyborach do PE. Europa dotychczas kojarzona z dobrobytem współcześnie postrzegana jest raczej przez pryzmat wysokiego bezrobocia (szczególnie wśród osób młodych), obniżenia poziomu życia w niektórych państwach członkowskich, braku (lub niewielkiego) wzrostu gospodarczego. Kryzys gospodarczy w wielu państwach członkowskich przyczynił się do wzrostu zadłużenia, a w konsekwencji do konieczności rozpoczęcia oszczędności (czasem drastycznych). Wydaje się także, że różnice między krajami w zakresie rozwoju gospodarczym stały się bardziej zauważalne. Wiele krajów strefy euro stanęło w obliczu dużych problemów gospodarczych. Znalazły się wśród nich: Grecja (konieczność zaprzestania ciągłego zadłużania państwa), Hiszpania (bardzo wysoki poziom bezrobocia), Cypr (problemy na rynku bankowym) czy Irlandia (problemy związane z rynkiem nieruchomości). W reakcji na problemy sektora bankowego wprowadzano „pakiety ratunkowe” czy ,pakiety stymulacyjne”, co wpłynęło na stan finansów publicznych państw, prowadząc do ich nadmiernego zadłużania się (kryzys zadłużeniowy np. w Irlandii [Riedel 2015]). Ponadto zauważalna jest w Europie „dwubiegunowość” poglądów, która utrudnia skuteczne rozwiązanie kryzysu, prowadząc jednocześnie do generowania sceptycznych postaw wobec UE. Z jednej strony bowiem obywatele tzw. krajów peryferyjnych sprzeciwiają się kolejnym oszczędnościom, domagają się bardziej sprawiedliwej dystrybucji kosztów kryzysu, z drugiej zaś w krajach uznawanych za bogatsze obywatele nie aprobują nadmiernej dystrybucji wpracowanych przez nich środków (funduszy z ich podatków) na rzecz ratowania sytuacji w innych państwach [Grosse 2014].

Od kilku lat w UE zauważalny jest również kryzys demokracji. Krytykuje się głównie słabą legitymizację i niewystarczający udział obywateli w kształtowaniu UE. J. Zielonka [2014, s. 62-63] zauważa, że: „(...) z jednej strony, UE wymaga programów oszczędnościowych, zakazuje interwencji banków centralnych, nie godzi się na podejmowanie suwerennych uchwał przez parlamenty narodowe, odrzuca demokratycznie wybranych polityków. Z drugiej - nie chroni przed nieregulowanymi rynkami, nie uspołecznia zadłużenia ani nie dopuszcza obywateli do swych rozstrzygnięć (...). Unią kieruje wąska grupa elit przy znikomym udziale obywateli. Tym ostatnim nie pozostaje nic innego, jak przystępować do stale zmieniających się układów - bez możliwości wypowiedzenia się w sprawie ich zakresu i kształtu”. Wydaje się, że podobne postulaty przywoływane są również przez zwolenników poglądów eurosceptycznych. Wobec deficytu demokracji w Europie formułowanych jest wiele zarzutów. T. Grosse [2014] wskazuje na brak ogólnoeuropejskiej debaty, która miałaby być platformą pozwalającą wyrażać i identyfikować interesy szczebla europejskiego i byłaby 
wspierana przez media europejskie, czy niewystarczającą liczbę ogólnoeuropejskich organizacji obywatelskich, które miałyby realny wpływ na kształtowanie się opinii publicznej. Dodatkowo wskazuje na pewnego rodzaju słabość wyborów europejskich (do Parlamentu Europejskiego), które zazwyczaj traktowane są jako drugorzędne w stosunku do wyborów krajowych, a partie w nich uczestniczące zwracają zwykle uwagę na aspekty wewnątrzkrajowe [Grosse 2014]. W kontekście kryzysu demokracji warto także wskazać na duże różnice poziomu frekwencji wyborczej pomiędzy krajami członkowskimi, a także jakość i dojrzałość europejskiego społeczeństwa obywatelskiego.

Na nastroje Europejczyków silnie oddziałuje również kryzys migracyjny. Warto wspomnieć, że imigracja znalazła się wśród największych obaw (wyzwań) wskazywanych przez Europejczyków. Takiego zdania jest niemal co drugi obywatel w UE (48\%). Obawa związana z imigracją wymieniania jest częściej niż sytuacja gospodarcza (19\%), stan finansów publicznych państw członkowskich (16\%) czy bezrobocie (15\%) [Standard Eurobarometer... 2016]. Wydaje się jednocześnie, że nie pojawiły się jak dotąd (koniec 2016 r.) wystarczająco skuteczne rozwiązania na poziomie europejskim pozwalające na poradzenie sobie z dużą liczbą imigrantów napływających do Unii Europejskiej. Według sondażu Pew Research Center z 2016 r. przeprowadzonego w 10 państwach członkowskich, które reprezentują blisko 80\% ludności UE, Europejczycy negatywnie postrzegają europejską politykę migracyjną. Nie aprobuje tej polityki blisko 94\% Greków, 88\% Szwedów, 77\% Włochów, 75\% Hiszpanów, 72\% Węgrów, 71\% Polaków, 70\% Francuzów i 67\% Niemców [Stokes 2016].

Wydaje się, że kryzys w wymienionych sferach implikuje kryzys samego projektu Unii Europejskiej. Przejawem negatywnych postaw były wyniki referendum w Wielkiej Brytanii, w którym Brytyjczycy opowiedzieli się za wyjściem z Unii Europejskiej. UE stanęła przed istotnym dylematem dotyczącym przyszłości idei integracji europejskiej wobec procesu dezintegracji. Kryzys ten wzmacniany jest także przez odradzającą się w Europie koncepcję państwa narodowego. J. Zielonka [2014] zauważa, że rośnie rola wielkich miast czy regionów, a także organizacji pozarządowych. Ponadto współczesna UE musi zmierzyć się także z utratą zaufania. Według badań opublikowanych w 2016 r. tylko 33\% Europejczyków darzy Unię Europejską zaufaniem, średnio co czwarty ma do niej negatywne nastawienie (27\%), a tylko $34 \%$ ma nastawienie pozytywne. Warto wspomnieć, że w 2006 r. co drugi Europejczyk miał wobec UE nastawienie pozytywne (50\%), a tylko $15 \%$ obywateli miało nastawienie negatywne. Dwie trzecie Europejczyków czuje się obywatelami UE (66\% w 2016 r.), ale tylko 38\% uważa, że ich głos ma znaczenie [Standard Eurobarometer... 2016]. Według sondażu Pew Research Center w Grecji i Wielkiej Brytanii ponad 60\%, a w Szwecji, Holandii, Niemczech i na Węgrzech ponad $40 \%$ obywateli opowiada się za decentralizacją 
władzy w Unii i powrotem niektórych kompetencji na poziom krajowy. Spośród 10 państw objętych badaniem tylko we Francji (34\%) i w Hiszpanii (30\%) niemal co trzeci obywatel popiera przekazanie jeszcze większej władzy na poziom ponadnarodowy [Stokes 2016].

Popularność poglądów eurosceptycznych należy w kontekście przyszłości idei integracji postrzegać w dwóch wymiarach: pozytywnym (jako korzyść) i negatywnym (jako zagrożenie). Odwołując się do zasad pluralizmu politycznego czy zasad państwa demokratycznego, poglądy eurosceptyczne należy postrzegać jako przejaw istnienia antyunijnych poglądów, które w sposób demokratyczny wpływają na zmianę układu sił politycznych w niektórych państwach członkowskich. Pozytywnym aspektem tej zmiany może być zatem impuls dla Unii Europejskiej wywołany przez partie eurosceptyczne na rzecz reintegracji, zmiany w funkcjonowaniu tej organizacji. Wydaje się bowiem, że istnieje pilna potrzeba wypracowania wiarygodnych alternatywnych sposobów współpracy. Wymaga to jednak nie tylko wyrażania krytyki wobec Unii Europejskiej, ale też wskazania możliwych rozwiązań. Niestety eurosceptycyzm może stać się również zagrożeniem dla Unii Europejskiej, jeśli zacznie być wykorzystywany do wzmacniania negatywnych nastrojów, szczególnie przez partie populistyczne czy wręcz nacjonalistyczne. Istnienie poglądów eurosceptycznych w Europie jest faktem, który jest dodatkowo wzmacniany przez istniejące kryzysy. Postulaty zgłaszane przez eurosceptyków wpłyną na przyszłość Unii Europejskiej, ale otwarte pozostaje pytanie, czy będzie to wpływ pozytywny, czy negatywny.

\section{Podsumowanie}

Poglądy sceptyczne wobec procesu integracji europejskiej czy Unii Europejskiej istnieją od dawna. W ostatnich latach stały się one jednak bardziej zauważalne na europejskiej scenie politycznej. Wzrosła liczba europosłów w PE reprezentujących poglądy eurosceptyczne, zarówno te radykalne, jak i umiarkowane. Partie, dla których charakterystyczne są takie poglądy, są również obecne na krajowej scenie politycznej w wybranych państwach członkowskich. Eurosceptycyzm zauważany jest zatem w politycznym dyskursie na poziomie zarówno europejskim, jak i krajowym.

Uwzględniając obecne uwarunkowania społeczno-gospodarcze i liczne wyzwania, przed którymi stanęła UE, nie należy jednak w najbliższym czasie spodziewać się ani pogłębiania, ani poszerzania integracji. Póki co wydaje się, że „Unia Europejska stała się zbyt wielka, by upaść” [Zielonka 2014, s. 132]. Nie zmienia to jednak faktu, że wymaga wprowadzenia zmian, rozpoczęcia procesu reintegracji, a także wdrożenia skutecznych rozwiązań wobec kryzysu migra- 
cyjnego czy kryzysu demokracji. Eurosceptycy mogą zatem paradoksalnie stać się szansą dla przyszłości europejskiego projektu. Ważne jest, by ich postulaty były spójne i nie koncentrowały się wyłącznie na krytyce zdezaktualizowanej ich zdaniem koncepcji europejskiego projektu, a stanowiły źródło alternatywnych rozwiązań. Eurosceptycy w PE są przedstawicielami różnych grup politycznych. Istnieje zatem potrzeba ich większej konsolidacji i wspólnego przekazywania konstruktywnych postulatów. Dotyczy to szczególnie tych europosłów, którzy reprezentują poglądy bardziej umiarkowane. Należy zauważyć, że impuls do zmian płynący z Parlamentu Europejskiego mógłby przyczynić się nie tylko do rozpoczęcia procesu reintegracji, ale także do wzmocnienia pozycji PE w systemie instytucjonalnym UE. Ze względu na obecne uwarunkowania i układ sił politycznych w PE, ten postulat może być trudny do zrealizowania. Wydaje się jednak, że UE nie powinna marginalizować poglądów eurosceptycznych, lecz starać się je usłyszeć w imię zachowania wartości, jaką jest idea integracji.

\section{Literatura}

Bertoncini Y., Koenig N. [2014], Euroscepticism or Europhobia: Voice vs. Exit?, Notre Europe - Jacques Delors Institute, Policy Pappers 121.

Condruz-Băcescu M. [2014], Euroscepticism Across Europe: Drivers and Challenges, „European Journal of Interdisciplinary Studies”, vol. 6, nr 2.

The Eurosceptic Union [2014], „The Economist”, http://www.economist.com/news/ europe/21603034-impact-rise-anti-establishment-parties-europe-and-abroad-eurosceptic-union (data dostępu: 6.11.2016).

Grosse T. [2014], Kryzys demokracji w Europie, „Przegląd Europejski”, nr 3.

Harmsen R., Spiering M. [2004], Introduction: Euroscepticism and the Evolution of European Political Debate, „European Studies”, $\mathrm{nr} 1$.

Kopecký P., Mudde C. [2002], The Two Sides of Euroscepticism. Party Positions on European Integration in East Central Europe, „European Union Politics”, vol. 3, nr 3, https://doi.org/10.1177/1465116502003003002.

Łada A. [2014], Znaczenie eurosceptyków w Parlamencie Europejskim nowej kadencjiwnioski z pierwszych miesięcy po wyborach, Instytut Spraw Publicznych, Warszawa.

Moroska A. [2010], Prawicowy populizm a eurosceptycyzm. Na przykładzie Listy Pima Fortuyna w Holandii i Ligii Polskich Rodzin w Polsce, Wydawnictwo Uniwersytetu Wrocławskiego, Wrocław.

Riedel R. [2015], Eurosceptycyzm w kontekście kryzysu gospodarczego w Europie, „Studia Ekonomiczne. Zeszyty Naukowe Uniwersytetu Ekonomicznego w Katowicach”, nr 228.

Riedel R., Zuba K. [2015], EUROsceptycyzm - propozycja konceptualizacji, „Przegląd Europejski", nr 3.

Standard Eurobarometer 85 [2016], European Union, Spring.

Staszczyk A. [2014], Parlament Europejski - sukces eurosceptyków: komentarz do wyników wyborów europejskich z 2014 r., ,Biuletyn Instytutu Zachodniego”, nr 166. 
Stokes B. [2016], Euroskepticism Beyond Brexit, Pew Research Center, http://www.pewglobal.org/2016/06/07/euroskepticism-beyond-brexit/ (data dostępu: 11.11.2016).

Taggart P. [1998], A Touchstone of Dissent: Euroscepticism in Contemporary Western European Party Systems, „European Journal of Political Research”, vol. 33, nr 3, https://doi.org/10.1111/1475-6765.00387.

Taggart P., Szczerbiak A. [2003], Theorising Party-based Euroscepticism: Problems of Definition, Measurement and Causality, ,Sussex European Institute Working Paper”, nr 69.

Toomey M. [2007], Euroscepticism in Central Europe: A Comparative Analysis at Elite and Mass Level of Poland, the Czech Republic, and Slovakia, MEA, Lund University, Department of Political Science.

Wyniki wyborów do Parlamentu Europejskiego w 2014 roku [2014], http://www.europarl. europa.eu/elections2014-results/pl/election-results-2014.html (data dostępu: 6.11.2016).

Zielonka J. [2014], Koniec Unii Europejskiej?, PISM, Warszawa.

\section{European Integration in View of Euroscepticism}

(Abstract)

Eurosceptical views are more and more often evident in the programmes and activities of European political parties, and are manifested in the political debate transpiring in Member States. Is Euroscepticism an opportunity or a threat for the future of the idea of European integration? Does it threaten the cohesion of the European project? The main aim of this article is to answer these questions.

Euroscepticism and the categorizations it breaks down into are defined in the article. Empirical analysis and a review of the literature are used to illustrate the importance of Eurosceptics in the European Parliament. This study identifies why Eurosceptical views in Europe have become more popular, pointing to the existence of many European crises, including in the economy, migration and democracy.

The number of Eurosceptics in the EP has increased, but they come from different political groups. If their opinions are to be seen as an opportunity for the future of the EU, their demands must be consolidated and infused with greater coherence. Eurosceptical views should not be marginalized in the context of the further development of the EU.

Keywords: Euroscepticism, the European Parliament, Europhobes, political groups. 